\title{
Kualitas Soal Penilaian Akhir Semester (PAS) Buatan Guru Mata Pelajaran Kimia Kelas X SMK Jurusan Teknologi Dan Rekayasa Di Kabupaten Kotawaringin Timur Pada Semester Ganjil Tahun Ajaran 2018/2019
}

\author{
Ngodithya Salvina, Suandi Sidauruk, Nopriawan Berkat Asi \\ Program Studi Pendidikan Kimia, FKIP, Universitas Palangka Raya, Indonesia
}

\begin{abstract}
Abstrak: Penelitian ini bertujuan untuk mengetahui dan mendeskripsikan tingkat kualitas soal PAS buatan guru mata pelajaran kimia kelas X SMK Jurusan Teknologi dan Rekayasa di Kabupaten Kotawaringin Timur pada semester ganjil tahun ajaran 2018/2019. Penelitian ini termasuk penelitian deskriptif. Subjek penelitian adalah soal buatan guru dan jawaban siswa hasil ulangan akhir semester. Teknik pengumpulan data dalam penelitian ini adalah metode dokumentasi. Analisis data dilakukan dengan menggunakan teknik analisis logical review dan empirical review. Hasil penelitian analisis logical review tingkat kesesuaian butir soal dengan indikator dalam silabus K13 sebesar 97,48\%, dengan aspek materi, konstruksi dan bahasa sebesar 98,72\%. Distribusi tingkat kognitif taksonomi bloom 52 (55\%) soal kognitif C1, 23 (24\%) soal kognitif C2, 17 (18\%) soal kognitif C3, 3 (3\%) soal tingkat C4, kesesuaian dengan kompetensi dasar sebesar $69,5 \%$. Analisis secara empirical review reliabilitas 0,570 (cukup), daya beda $75,7 \%$ soal baik, tingkat kesukaran butir soal 43,3\% kategori sedang dan efektifitas distraktor $76,42 \%$ efektif.
\end{abstract}

\section{Kata Kunci: Daya beda, Efektifitas distraktor, Kualitas soal, Reliabilitas, Tingkat kesukaran}

\section{Pendahuluan}

Mutu pendidikan yang berkualitas sangat diperlukan untuk mendukung terciptanya manusia yang cerdas dan berkehidupan damai, terbuka, dan berdemokrasi, serta mampu bersaing secara terbuka di era global (Hidayatullah, 2006). Sumber daya manusia yang berkualitas dapat membawa kemajuan ilmu pengetahuan dan teknologi (IPTEK) di segala aspek kehidupan dan membawa manusia kepada peradaban yang lebih maju dengan pola pikir yang logis. Kualitas sumber daya manusia dapat ditingkatkan dengan cara meningkatkan kualitas di sekolah yang ditentukan oleh berbagai faktor. Faktor tersebut antara lain guru, murid, proses pembelajaran, lingkungan, sarana dan prasarana pembelajaran serta waktu pembelajaran (Johnson, 2008).

Tujuan pokok proses pembelajaran adalah untuk mengubah tingkah laku peserta didik berdasarkan tujuan yang telah direncanakan dan disusun oleh pendidik sebelum proses kegiatan pembelajaran berlangsung (Hamalik, 2010). Ketika proses pembelajaran dipandang sebagai proses perubahan tingkah laku peserta didik, peran penilaian dalam proses pembelajaran menjadi sangat penting (Slamento, 2001). Penilaian dalam proses pembelajaran merupakan suatu proses untuk mengumpulkan, menganalisa dan menginterpretasi informasi untuk mengetahui tingkat pencapaian tujuan pembelajaran (Novianto, 2012).

Masalah yang sering terjadi baik pada tes yang dibuat oleh guru mata pelajaran maupun Musyawarah Guru Mata Pelajaran (MGMP) ternyata tidak melalui uji coba soal, tidak adanya uji coba soal maka soal tersebut belum terstandar atau belum memenuhi kriteria tes yang baik. Realita di lapangan juga 
banyak ditemui guru dalam menyusun tes hanya berpatokan pada proporsi materi dan belum diketahui apakah tes yang digunakan tersebut telah tersusun atas butirbutir yang baik, sehingga menghasilkan tes yang terlalu mudah atau bahkan terlalu sulit. Tes yang terlalu mudah membuat siswa tidak terangsang untuk belajar lebih giat, sebaliknya tes yang terlalu sulit menyebabkan siswa putus asa karena diluar jangkauan kemampuannya (Marlina, 2018).

Tes merupakan alat ukur untuk proses pengumpulan data di mana dalam memberikan respon atas pertanyaan dalam instrumen, peserta didorong untuk menunjukan kemampuan maksimalnya. Peserta diharuskan mengeluarkan kemampuan semaksimal mungkin agar data yang diperoleh dari hasil jawaban peserta didik benar-benar menunjuk kemampuannya (Purwanto, 2009). Tes hasil belajar merupakan sumber data bagi guru untuk mengetahui berapakah nilai peserta didik. Tes hasil belajar juga dapat dijadikan sebagai evaluasi bagi guru maupun pihak sekolah (Elis, 2015).

Tes hasil belajar dapat dikelompokkan menjadi beberapa macam. Menurut peranan fugsionalnya dalam pembelajaran, tes hasil belajar dibagi menjadi empat macam yaitu (Purwanto, 2016): (1) Tes formatif digunakan untuk mengetahui sejauh mana kemampuan peserta didik setelah mengikuti proses belajar mengajar; (2) Tes sumatif sebagai tes yang digunakan untuk mengetahui penguasaan siswa atas semua jumlah materi yang disampaikan dalam satuan kurun waktu tertentu seperti semester; (3) Evaluasi belajar mempunyai fungsi diagnostik; (4) Tes penempatan adalah tes hasil belajar yang dilakukan untuk menempatkan peserta didik dalam kelompok yang sesuai dengan kempuan ataupun bakat minatnya.

Evaluasi memiliki peranan penting dalam proses pembelajaran. Dalam proses pembelajaran, guru akan mengatur seluruh rangkaian kegiatan pembelajaran, mulai dari membuat desain pembelajaran, melaksanakan kegiatan pembelajaran, bertindak mengajar atau melakkan evaluasi termasuk proses dan hasil belajar yang berupa dampak pengajaran (Arifin, 2009).

Tes buatan guru (teacher-made test) adalah tes yang disusun sendiri oleh guru yang akan mempergunakan tes tersebut (Arifin, 2009). Tes buatan guru dimaksudkan untuk mengukur tingkat penguasaan peserta didik dalam mencapai kompetensi dan materi pelajaran setelah berlangsungnya proses pembelajaran yang dikelola oleh guru kelas yang bersangkutan (Afrian, 2018).

Tes pilihan ganda adalah tes di mana setiap butir soalnya memiliki jumlah alternatif jawaban lebih dari satu. Pada umumnya jumlah alternatif jawaban berkisar antara 2 (dua) atau 5 (lima). Tipe tes ini dalam bahasa Inggris dikenal dengan nama multiple choice item (butir soal pilihan majemuk atau ganda) (Widyoko, 2014).

Tujuan melakukan analisis butir soal menurut penuturan Daryanto (2008) adalah untuk mengidentifikasi soal-soal baik, kurang baik, dan soal jelak dan memperoleh petunjuk untuk melakukan perbaikan. Cara menilai tes yaitu: (1) meneliti secara jujur soal-soal yang sudah disusun; (2) mengadakan analisis soal; (3) mengadakan checking validitas dan (4) mengadakan checking reliabilitas, dan didalam poin dua yaitu mengadakan analisis soal terdapat tiga pendekatan yang dapat digunakan yaitu (a) taraf kesukaran; (b) daya pembeda; dan (c) pengecoh.

Dua cara yang dapat digunakan dalam penelaahan butir soal, yaitu penelaahan soal secara kualitatif dan kuantitatif. Analisis butir soal secara logical 
review merupakan analisis butir soal secara kualitatif yang prinsipnya dilaksanakan berdasarkan kaidah penulisan soal (Yaspuri, 2014). Aspek yang diperhatikan dalam penelaahan soal secara kualitatif adalah setiap soal ditelaah dari segi materi, kontruksi, bahasa/budaya dan kunci jawaban/pedoman penskoran, tingkat kognitif yang harus dicapai siswa selama dilaksanakannya pembelajaran.

Penelaahan soal secara kuantitatif adalah penelaahan butir soal didasarkan pada data empiris dari butir soal yang bersangkutan. Data empiris ini diperoleh dari soal yang telah diujikan berupa angka-angka numerik. Aspek yang perlu diperhatikan dalam analisis butir soal secara empiris adalah butir soal ditelaah dari segi: (1) tingkat kesukaran, (2) validitas, (3) reliabilitas, (4) daya beda, (5) efektifitas distraktor (Hamdi, 2015).

Beberapa program bantu komputer sudah dikenal untuk menganalisis soal diantaranya Excel, ITEMAN, dan SPSS. Penjelasan singkat mengenai programprogram tersebut diantaranya adalah sebagai berikut: 1) Miscrosoft Excel adalah sebuah program aplikasi lembar kerja spreadsheet yang dibuat dan didistribusikan oleh MS. Keunggulannya adalah peneliti bisa lebih tepat menuliskan rumus/ perintah yang diinginkan, excel memiliki fitur grafik, dan exel mempunyai kemampuan data yang cukup besar. (Hardiyaningrum, 2013); 2) Item dan Test Analysis (Iteman), Aplikasi ini merupakan dibuat khusus untuk analisis butir soal (Kartowagirang, 2005). Keunggulannya adalah, program Iteman dikhususkan untuk analisis butir dengan kapasitas 3.000 responden. ; 3) SPSS, ditujukan bagi pengolahan data statistik untuk ilmu sosial kini telah diperluas untuk melayani berbagai jenis user seperti untuk riset sains dan statistic. Keunggulan dari SPSS yaitu mampu mengolah data dari berbagai program hitung lain, disediakan berbagai rumus analisis dan mampu menampilkan banyak angka pada fungsifungsi statistik dan kemudian mempresentasikannya dengan format termasuk format grafis (Yamin, 2009).

Sesuai dengan kompetensi dasar mata pelajaran SMK, menyatakan mata pelajaran kimia termasuk dalam kategori mata pelajaran muatan nasional (psmk, 2017). Kompetensi dasar SMK terdiri dari 20 pokok bahasan kimia. Pokok Bahasan tersebut yaitu, Materi dan Peubahan, Lambang Unsur, Rumus Kimia, dan Persamaan Reaksi, Struktur atom dan SPU, Ikatan Kimia, Konsep Mol, Larutan, Redoks, Elektrokimia, Senyawa Hidrokarbon, dan Polimer. Sesuai dengan Kurikulum 2013 yang berlaku, maka masing-masing sekolah diberikan wewenang dalam menentukan jumlah pokok bahasan yang di ajarakan. Rumusan masalah dalam penelitian ini adalah: bagaimana kualitas soal penilaian akhir semester (PAS) buatan guru mata pelajaran kimia Kelas X SMK Jurusan Teknologi dan Rekayasa di Kabupaten Kotawaringin Timur pada semester ganjil tahun ajaran 2018/2019? Penelitian ini bertujuan untuk mengetahui dan mendeskripsikan tingkat kualitas soal penilaian akhir semester (PAS) buatan guru mata pelajaran kimia Kelas X SMK Jurusan Teknologi dan Rekayasa di Kabupaten Kotawaringin Timur pada semester ganjil tahun ajaran 2018/2019.

\section{Metode Penelitian}

Pengambilan data ini dilaksanakan di 3 sekolah yaitu SMKN 2 Sampit (SMK A), SMKN 3 Sampit (SMK B) dan SMK Muhammadiyah Sampit (SMK C). Penelitian ini dilakukan pada 29 Maret hingga 12 Februari 2019. Objek dalam 
penelitian ini adalah soal buatan guru dan jawaban siswa hasil penilaian akhir semester (PAS) mata pelajaran kimia kelas X Jurusan Teknologi dan Rekayasa di Kabupaten Kotawaringin Timur pada semester ganjil tahun ajaran 2018/2019. Soal buatan guru dan lembaran jawaban siswa akan diambil dari SMKN 2 Sampit, SMKN 3 Sampit, dan SMK Muhammadiyah Sampit tahun ajaran 2018/2019. Pengumpulan data dalam penelitian ini menggunakan metode dokumentasi. Data yang dikumpulkan pada penelitian ini berupa data sekunder. Data sekunder yang digunakan dalam penelitian ini berupa lembar soal buatan guru kimia kelas $\mathrm{X}$ Jurusan Teknologi dan Rekayasa SMK dalam bentuk pilihan ganda beserta lembar jawaban dari peserta tes. Soal buatan guru kimia kelas X Jurusan Teknologi dan Rekayasa di SMKN 2 Sampit, SMKN 3 Sampit, SMKN Muhammadiyah Sampit. Teknik Analisis data dalam penelitian ini berupa analisis deskriptif, yaitu suatu teknik untuk mengungkapkan dan memaparkan pendapat data dari responden dan yang diperoleh dilapangan. Setelah itu dilakukan data secara deskriptif yaitu dengan cara memaparkan secara objektif dan sistematis situasi yangada dilapangan. Soal kimia buatan guru kimia kelas X SMK Jurusan Teknologi dan Rekayasa beserta lembar jawaban yang sudah diisi siswa selanjutnya dianalisis. Ada dua cara yang digunakan yaitu dianalisis secara logical review dan empirical review. Analisis kualitatif dalam penelitian ini yaitu analisis untuk menentukan validitas isi soal. Sedangkan analisis kuantitatif digunakan untuk mencari reliabilitas, indeks daya beda, indeks tingkat kesukaran dan efektifitas distraktor.

\section{Hasil Penelitian Dan Pembahasan}

Aspek yang diperhatikan dalam analisis butir soal secara logical review pada penelitian ini adalah data validitas isi soal. Data hasil analisis didapat dari pendapat ahli yang sudah mengisi instrumen validasi soal. Ahli yang dimaksud adalah 8 orang rater, yaitu 3 orang dosen kimia dan 5 orang mahasiswa yang telah menempuh dan lulus seluruh mata kuliah berkaitan dengan analisis butir soal. Setiap butir soal ditelaah dari segi kesesuain butir soal dengan aspek materi, kontruksi dan bahasa, kompetensi dasar dan ranah kognitif taksonomi Bloom.

Ringkasan data yang diperoleh dari kesesuaian soal dengan materi, konstruksi dan bahasa SMK A bentuk soal pilihan ganda dapat dilihat pada Gambar 1.

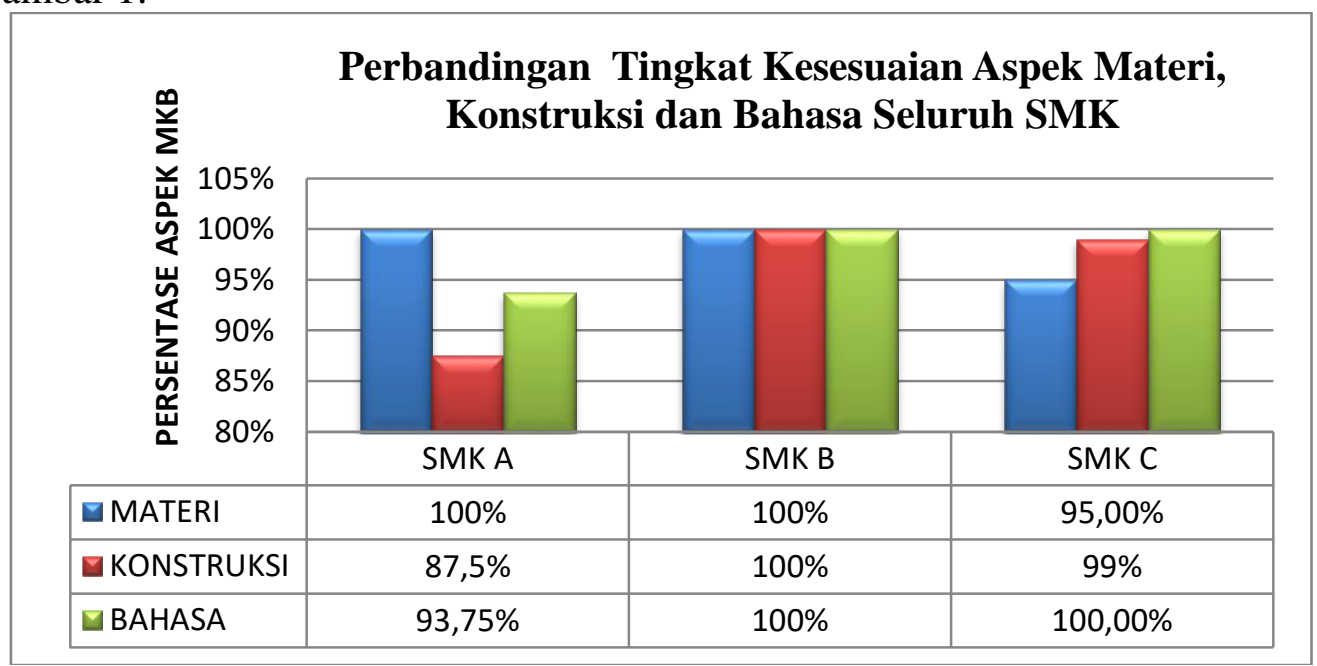

Gambar 1. Perbandingan Tingkat Kesesuaian Aspek Materi, Konstruksi dan Bahasa Seluruh SMK 
Jurnal Ilmiah Kanderang Tingang 10(1) (2019) 46-56 ISSN 2087-166X

Januari-Juni 2019
Fakultas Keguruan dan Ilmu Pendidikan

Universitas Palangka Raya

https://chem-upr.education/ojs

Ringkasan data yang diperoleh dari kesesuaian soal dengan Kompetensi dasar bentuk soal pilihan ganda dapat dilihat pada Gambar 2.

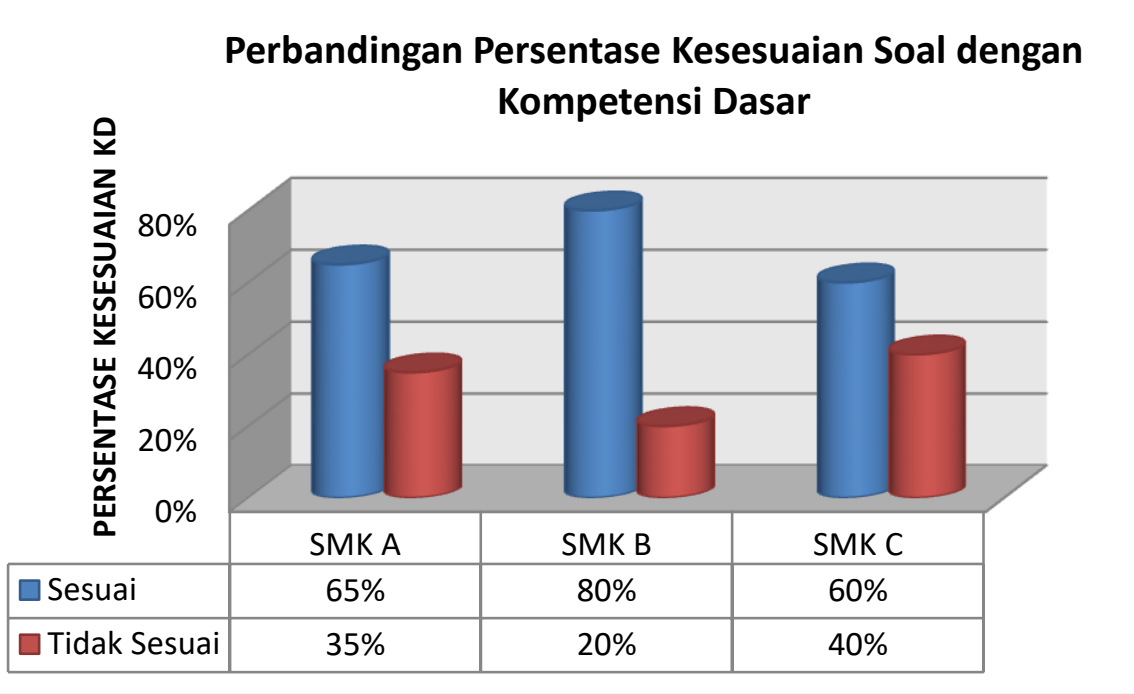

Gambar 2. Perbandingan Persentase Kesesuaian Soal dengan Kompetensi Dasar

Gambar 3 menunjukkan pengelompokkan soal tiap sekolah berdasarkan tingkatan kognitif menurut taksonomi Bloom.

\section{Perbandingan Tingkat Taksonomi Bloom pada Tiap Sekolah}

$\mathrm{C} 1=$ Mengingat $\mathrm{C} 2=$ Memahami $\mathrm{C} 3=$ Menerapkan $\mathrm{C} 4=$ Menganalisis $\mathrm{C} 5=$ Mengevaluasi $\mathrm{C} 6=$ Mencipta

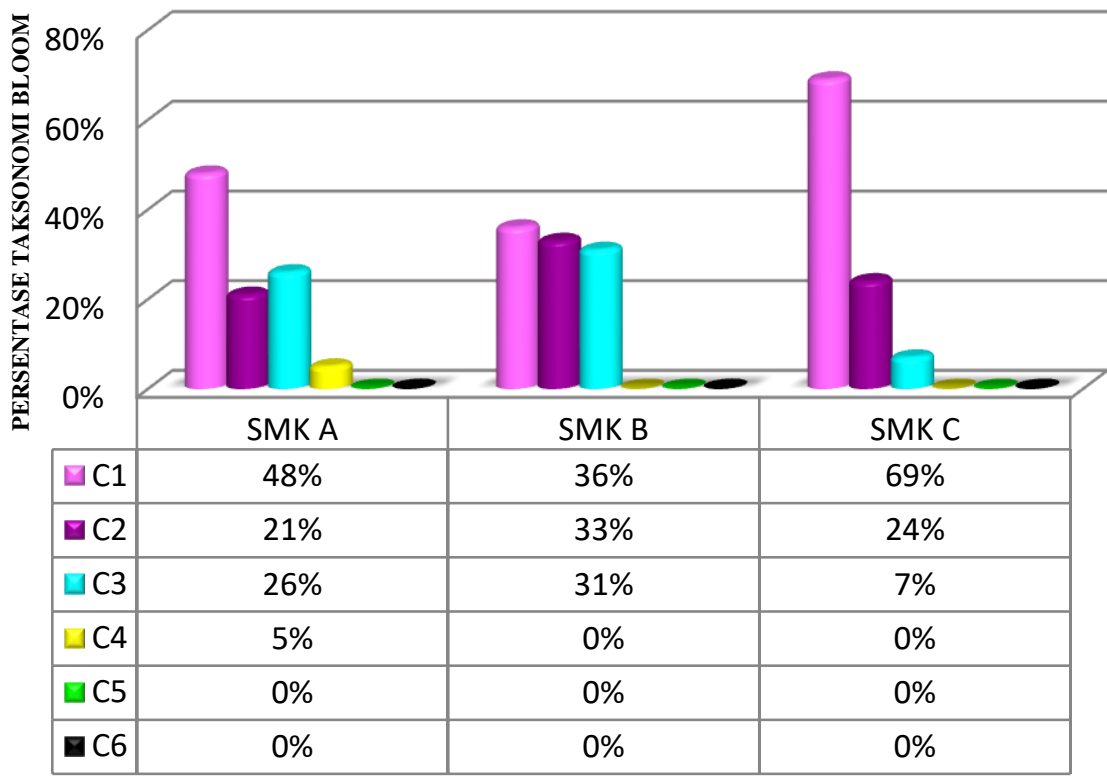

Gambar 3. Perbandingan Tingkat Taksonomi Bloom pada Tiap Sekolah

Hasil analisis reabilitas soal PAS dari tiga sekolah yang telah diteliti disajikan dalam Tabel 1. 
Tabel 1. Hasil Analisis Reliabilitas Soal Tiap Sekolah

\begin{tabular}{ccccc}
\hline Sekolah & $\mathrm{R}$ & Keterangan & $\overline{\mathrm{R}}$ & Keterangan \\
\cline { 1 - 3 } $\mathrm{A}$ & 0,595 & Cukup & & \\
$\mathrm{y}$ & 0,408 & Rendah & 0,570 & Cukup \\
\hline $\mathrm{C}$ & 0,708 & Tinggi & & \\
\hline
\end{tabular}

Hasil analisis daya beda butir soal dari tida sekolah yang telah diteliti disajikan dalam Gambar 4.

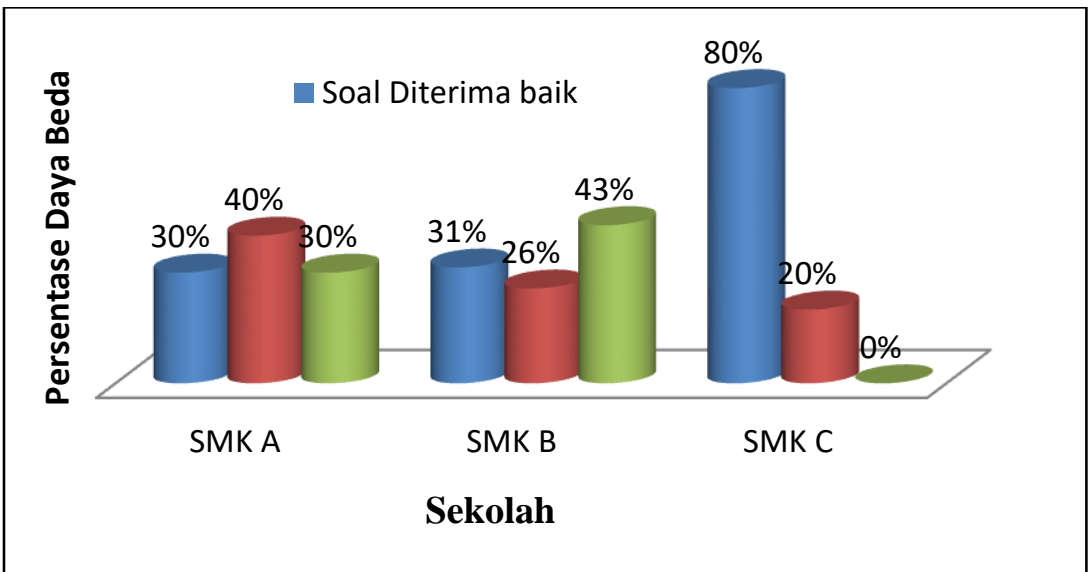

Gambar 4. Perbandingan Daya Pembeda pada Tiap Sekolah

Hasil pengujian tingkat kesukaran soal PAS kelas X SMK Jurusan Teknologi dan Rekayasa semester ganjil dapat dilihat pada Gambar 5.

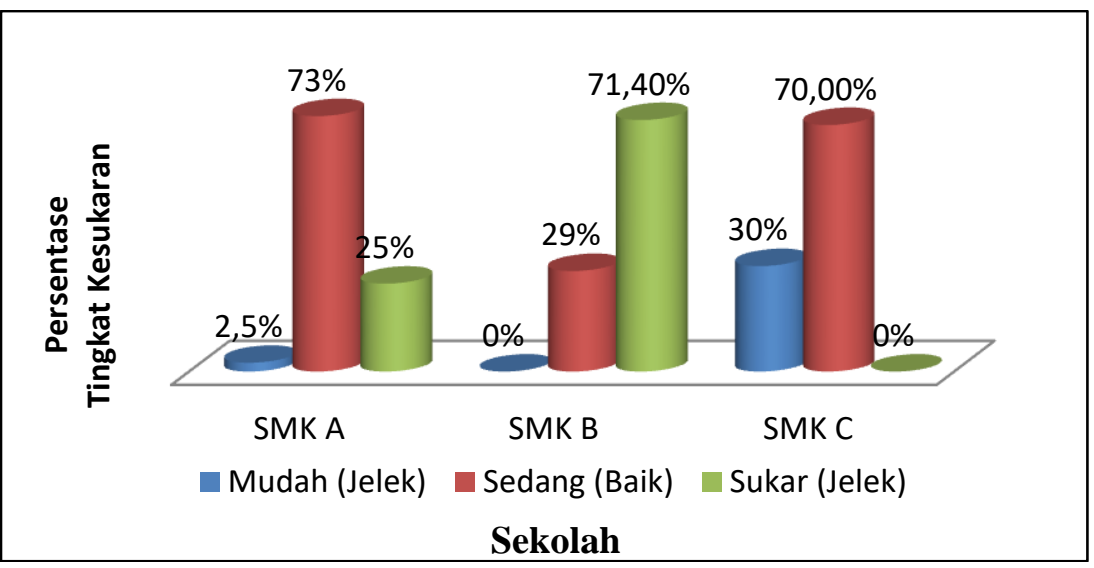

Gambar 5. Perbandingan Tingkat Kesukaran pada Tiap Sekolah

Perbandingan rincian distraktor yang berfungsi dan tidak berfungsi pada tiap pokok bahasan dapat dilihat pada Tabel 2 .

Tabel 2. Rincian Distraktor Pada Tiap Pokok Bahasan

\begin{tabular}{cccc}
\hline Pokok Bahasan & Kompetensi Dasar & SMK & $\begin{array}{c}\text { Distraktor yang } \\
\text { tidak berfungsi }\end{array}$ \\
\hline \multirow{2}{*}{$\begin{array}{c}\text { Materi dan } \\
\text { Perubahan }\end{array}$} & $\begin{array}{c}\text { Menganalisis perubahan materi } \\
\text { dan pemisahan campuran } \\
\text { dengan berbagai cara }\end{array}$ & $\mathrm{A}$ & 1 \\
\cline { 3 - 4 } & $\mathrm{B}$ & $\mathrm{C}$ & 7 \\
\hline Lambang unsur, & Menganalisis lambang unsur, & $\mathrm{A}$ & - \\
\hline
\end{tabular}




\begin{tabular}{|c|c|c|c|}
\hline Pokok Bahasan & Kompetensi Dasar & SMK & $\begin{array}{l}\text { Distraktor yang } \\
\text { tidak berfungsi }\end{array}$ \\
\hline \multirow{2}{*}{$\begin{array}{l}\text { rumus kimia dan } \\
\text { persamaan } \\
\text { reaksi }\end{array}$} & \multirow{2}{*}{$\begin{array}{l}\text { rumus kimia dan persamaan } \\
\text { reaksi }\end{array}$} & $\mathrm{B}$ & 1 \\
\hline & & $\mathrm{C}$ & - \\
\hline \multirow{3}{*}{$\begin{array}{l}\text { Struktur atom } \\
\text { dan SPU }\end{array}$} & \multirow{3}{*}{$\begin{array}{c}\text { Mengkorelasikan struktur atom } \\
\text { berdasarkan konfigurasi } \\
\text { elektron untuk menentukan } \\
\text { letak unsur dalam tabel } \\
\text { periodik }\end{array}$} & $\mathrm{A}$ & 1 \\
\hline & & $\mathrm{B}$ & 1 \\
\hline & & $\mathrm{C}$ & 6 \\
\hline \multirow[b]{2}{*}{ Ikatan kimia } & \multirow{2}{*}{$\begin{array}{c}\text { Menganalisis proses } \\
\text { pembentukan ikatan kimia } \\
\text { pada beberapa senyawa dalam } \\
\text { kehidupan sehari hari }\end{array}$} & $\mathrm{A}$ & - \\
\hline & & B & - \\
\hline Konsep Mol & $\begin{array}{c}\text { Menerapkan hukum-hukum } \\
\text { dasar kimia dalam perhitungan } \\
\text { kimia }\end{array}$ & A & - \\
\hline \multirow[t]{2}{*}{ Larutan } & $\begin{array}{c}\text { enganalisis sifat larutan } \\
\text { berdasarkan konsep asam basa } \\
\text { dan pH larutan (asam kuat dan } \\
\text { asam lemah, basa kuat dan } \\
\text { basa lemah) dalam kehidupan } \\
\text { sehari hari. }\end{array}$ & A & 1 \\
\hline & Jumlah & & 18 \\
\hline
\end{tabular}

Hasil analisis soal secara logical review dan empirical review dari seluruh sekolah yang diringkas dalam Tabel 3.

Tabel 3. Karakteristik soal buatan guru

\begin{tabular}{|c|c|c|c|}
\hline Karakteristik & SMK A & SMK B & SMK C \\
\hline Alokasi Waktu & 11.30-13.00 WIB & 11-00-12.30 WIB & 09-00-10.30 WIB \\
\hline Jumlah Soal & 40 & 35 & 20 \\
\hline Kurikulum & K13 & K13 & K13 \\
\hline $\begin{array}{l}\text { Kesesuaian soal } \\
\text { dengan aspek } \\
\text { materi }\end{array}$ & $\begin{array}{l}\text { Sangat baik } \\
97,5 \%\end{array}$ & $\begin{array}{l}\text { Sangat baik } \\
100 \%\end{array}$ & $\begin{array}{l}\text { Sangat baik } \\
95 \%\end{array}$ \\
\hline $\begin{array}{l}\text { Kesesuaian soal } \\
\text { dengan aspek } \\
\text { konstruksi }\end{array}$ & $\begin{array}{l}\text { Baik } \\
98,5 \%\end{array}$ & $\begin{array}{l}\text { Baik } \\
100 \%\end{array}$ & $\begin{array}{l}\text { Baik } \\
97,5 \%\end{array}$ \\
\hline $\begin{array}{l}\text { Kesesuaian soal } \\
\text { dengan aspek } \\
\text { bahasa }\end{array}$ & $\begin{array}{l}\text { Sangat baik } \\
100 \%\end{array}$ & $\begin{array}{l}\text { Sangat baik } \\
100 \%\end{array}$ & $\begin{array}{l}\text { Sangat baik } \\
100 \%\end{array}$ \\
\hline $\begin{array}{l}\text { Jenjang ranah } \\
\text { kognitif } \\
\text { Taksonomi } \\
\text { Bloom }\end{array}$ & $\begin{array}{l}\mathrm{C} 1=48 \% \\
\mathrm{C} 2=20,94 \% \\
\mathrm{C} 3=25,6 \% \\
\mathrm{C} 4=5,3 \% \\
\mathrm{C} 5=- \\
\mathrm{C} 6=-\end{array}$ & $\begin{array}{l}\mathrm{C} 1=36 \% \\
\mathrm{C} 2=32,9 \% \\
\mathrm{C} 3=31 \% \\
\mathrm{C} 4=- \\
\mathrm{C} 5=- \\
\mathrm{C} 6=-\end{array}$ & $\begin{array}{l}\mathrm{C} 1=69,4 \% \\
\mathrm{C} 2=23,8 \% \\
\mathrm{C} 3=6,9 \% \\
\mathrm{C} 4=- \\
\mathrm{C} 5=- \\
\mathrm{C} 6=-\end{array}$ \\
\hline
\end{tabular}




\begin{tabular}{|c|c|c|c|}
\hline Karakteristik & SMK A & SMK B & SMK C \\
\hline $\begin{array}{l}\text { Daya beda butir } \\
\text { soal }\end{array}$ & $\begin{array}{l}\text { Soal Diterima Baik } \\
=30 \% \\
\text { Soal Baik tapi } \\
\text { direvisi }=40 \% \\
\text { Soal Jelek }=30,5 \%\end{array}$ & $\begin{array}{l}\text { Soal Diterima } \\
\text { Baik = 31,4\% } \\
\text { Soal Baik tapi } \\
\text { direvisi }=25,7 \% \\
\text { Soal Jelek }= \\
42,9 \%\end{array}$ & $\begin{array}{l}\text { Soal Diterima Baik } \\
=80 \% \\
\text { Soal Baik tapi } \\
\text { direvisi }=20 \% \\
\text { Soal Jelek = - }\end{array}$ \\
\hline Tingkat & Mudah $=2,5 \%$ & Mudah = - & Mudah $=30 \%$ \\
\hline kesukaran butir & Sedang $=72,5 \%$ & Sedang $=28,6 \%$ & Sedang $=28,6 \% \%$ \\
\hline $\begin{array}{l}\text { soal } \\
\text { Reliabilitas }\end{array}$ & $\begin{array}{l}\text { Sukar }=25 \% \\
0,594 \text { (cukup) }\end{array}$ & $\begin{array}{l}\text { Sukar }=71,4 \% \\
0,408 \text { (rendah) }\end{array}$ & $\begin{array}{l}\text { Sukar = - } \\
0,708 \text { (Tinggi) }\end{array}$ \\
\hline $\begin{array}{l}\text { Efektifitas } \\
\text { distraktor }\end{array}$ & $\begin{array}{l}\mathrm{E}=86,25 \% \\
\mathrm{BE}=13,75 \%\end{array}$ & $\begin{array}{l}\mathrm{E}=94,28 \% \\
\mathrm{BE}=5,7 \%\end{array}$ & $\begin{array}{l}\mathrm{E}=48,75 \% \\
\mathrm{BE}=51,25 \%\end{array}$ \\
\hline
\end{tabular}

Dari aspek materi, kontruksi, dan Bahasa ketidaksesuaian yang paling tinggi dengan jumlah 2 soal yakni pada pilihan pokok soal dirumuskan dengn singkat, jelas dan tegas terdapat pada soal nomor 25 SMK A dan soal nomor 17 SMK C, 1 soal yakni pada pilihan gambar, grafik, tabel, diagram, atau sejenisnya (equation, persamaan reaksi dan konfigurasi elektron) jelas berfungsi terdapat pada soal nomor 7 pada SMK A, 1 soal merupakan pilihanan jawaban tidak homogen dan tidak logis, serta tidak terdapat satu kunci jawaban, soal tersebut terdapat pada SMK C dengan nomor soal 17, dan 1 soal merupakan pilihan jawaban ynag tidak disusun berdasarkan urutan besar kecilnya agka atau kronologinya, yaitu soal no 39 pada SMK A.

Hasil analisis yang telah dilakukan dengan bantuan 8 rater, didapatkan bahwa kebanyak bermasalah pada aspek konstruksi yaitu soal tidak dijelaskan secara singkat dan tegas, sehingga kemungkinan mengarahkan siswa kepada pilihan jawaban lebih dari satu. Dalam hal ini guru harus lebih memperhatikan perumusan permasalahan yang dapat dipahami oleh siswa secara jelas tanpa menimbulkan makna ganda dalam soal tersebut. Ditinjau dari aspek materi, konstruksi dan bahasa rata-rata persentase dari SMK A, SMK B, dan SMK C yaitu 9\% dengan kriteria soal sangat baik memenuhi aspek materi, 98,5\% dengan kriteria soal sangat baik memenuhi aspek konstruksi dan $100 \%$ dengan kriteria soal sangat baik memenuhi aspek bahasa.

Hasil analisis menunjukkan bahwa soal buatan guru mata pelajaran kimia kelas X SMK Jurusan teknologi dan rekayasa di kabupaten Kotawaringin Timur, sebanyak 95 soal yang terdiri dari 40 soal SMK A, 35 soal SMK B, dan 20 soal SMK C menerapkan kompetensi dasar sebagai tuntunan dalam membuat soal. Soal harus mampu menyakan prilaku dan materi materi yang hendak diukur sesuai dengan kompetensi dasar yang dikeluarkan oleh pemerintah pusat. Persentase aspek kesesuian butir soal dengan kompetensi dasar dari seluruh sekolah yaitu $69,5 \%$ (66 soal).

Sebaran soal yang terdapat pada SMK A hasil analisisnya sebanyak 26 (65\%) soal dari 40 soal yang diteskan tersebut sesuai, pokok bahasan yang paling banyak sesuai adalah pokok bahasan konsep mol. Sebaran soal yang terdapat pada SMK B hasil analisisnya merupakan persentase tertinggi untuk aspek kesesuaian butir soal dengan kompetensi dasar, sebanyak 28 (80\%) soal dari 35 soal yang diteskan tersebut sesuai, pokok bahasan yang paling banyak sesuai adalah pokok 
bahasan ikatan kimia. Pada SMK C sebanyak 12 (60\%) soal dari 20 soal yang sesuai dengan kompetensi dasar, soal yang sesuai dengan kompetensi dasar paling banyak pada pokok bahasan materi dan perubahan. Berikut contoh dan penjelasan kesesuian soal dan kompetensi dasar.

Ranah kognitif adalah ranah yang mencakup kegiatan mental (otak). Level kognitif merupakan tingkat kemampuan peserta didik secara individual maupun kelompok. Berdasarkan proses kognitif digunakan taksonomi bloom sebagai kata kerja dalam merumuskan kompetensi dasar atau indikator soal, sekaligus merupakan tingkatan proses berpikir.

Menurut modul Manajemen Implementasi Kurikulum 2013 Jenjang SMK (2013), menjelaskan tentang SKL (Standar Kompetensi Lulusan), KI (Kompetesi Inti), KD (Kompetensi Dasar). Untuk menentukan tingkat kognitif yang dibutuh pada jenjang SMK sesuai dengan Standar Kompetensi Kelulusan, maka fokus pertama adalah melakukan analisis terhadap ketiga standar kompetensi tersebut (SKL, KI, dan, KD). Dari hasil analisis itu akan diperoleh jabaran tentang taksonomi bloom dan gradasi hasil belajar yang berhubungan dengan materi pembelajaran, kegiatan pembelajaran, dan penilaian yang diperlukan. Kompetensi dasar menjadi tolak ukur analisis tingkat kognitif yang harus dicapai siswa. Untuk SMK kelas X jurusan Teknologi dan Rekayasa tingkat kognitif yang harus dicapai oleh peserta didik sesuai dengan analisis tingkat kognitf berdasarkan Kompetensi Dasar adalah 10\% C2, 20\% C3, 60\% C4, dan 10\% C5. Pada analisis data yang dilakukan oleh peneliti hanya ada 1 sekolah dengan jumlah butir soal sebanyak 3 (3\%) tingkat kognitif C4, yaitu SMK A, pada gambar 39 merupakan contoh soal C4.

Persentase ranah kognitif taksonomi bloom pada tiap sekolah diperoleh dari jumlah soal yang tergolong jenjang ranah kognitif dibagi dengan jumlah seluruh soal dari tiap sekolah. Sedangkan total persentase diperoleh dari jumlah keseluruhan soal dari SMK A, SMK B, dan SMK C yang tergolong ke dalam jenjang ranah kognitif dibagi dengan total soal dari ketiga sekolah SMK yang dianalisis. Hasil analisis tingkat kognitif penguasaan materi dari soal pilihan ganda yang didapat dari seluruh sekolah (SMK A, SMK B, dan SMK C) 95 soal menyatakan bahwa 52 (55\%) soal pada tingkat kognitif C1 (mengingat), 23 (24\%) soal pada tingkat kognitif C2 (memahami), 17 (18\%) soal pada tingkat kognitif C3 (menerapkan), 3 (3\%) soal pada tingkat C4 (menganalisis).

Reliabilitas soal penelitian ini di dapat dari nilai koefesien alpha atau Cronbach's alpha yang diperoleh dari program SPSS versi 16. Berdasarkan analisis diperoleh koefisien reliabilitas SMK A sebesar 0,594 dengan kriteria cukup, pada SMK B hasil analisis diperoleh koefisien reliabilitas SMK B sebesar 0,408 dengan kriteria rendah, dan SMK C hasil analisis diperoleh koefisien reliabilitas 0,708 dengan kriteria tinggi. Apabila hasil uji reliabilitas dari sekolah di Kabupaten Kotawaringin Timur dirata-ratakan maka didapat uji reliabilitas sebesar 0,570 dengan kategori cukup.

Hasil analisis memperlihatkan bahwa soal yang dapat membedakan siswasiswa yang termasuk kelompok (Super group) kelas atas dengan siswa-siswa yang termasuk kelompok kurang (lower group) kelas bawah dengan soal daya beda baik SMK C yaitu sebesar $80 \%$, dengan soal sebanyak 16 dari 20 soal. Soal dengan daya beda baik menandakan jika soal tersebut dapat membedakan kemampuan antara peserta tes yang pandai (kelompok atas) dengan peserta didik 
yang kurang pandai (kelompok bawah). Berikut hasil analisis daya beda dari beberapa sekolah.

Indeks tingkat kesukaran ini pada umumnya dinyatakan dalam bentuk numerik yang besarnya berkisar $0,00-1,00$. Artinya, angka indeks kesukaran itu paling rendah adalah 0,00 dan paling tinggi adalah 1,00. Angka indeks kesukaran sebesar 0,00 memberi arti bahwa soal tersebut termasuk dalam kategori soal yang sangat sukar karena seluruh siswa tidak dapat menjawab soal dengan benar. Sebaliknya apabila angka indeks kesukaran adalah 1,00 maka soal tersebut termasuk dalam soal yang sangat mudah karena seluruh siswa dapat menjawab dengan benar. Besarnya indeks kesukaran yang diterima untuk menyatakan soal yang baik adalah antara 0,30-0,70. Hasil analisis memperlihatkan bahwa secara keseluruhan 10,8\% soal tergolong mudah, 57\% soal tergolong sedang dan $32 \%$ soal tergolong sukar. Data menunjukkan hasil bahwa jumlah soal yang paling banyak pada kategori sedang pada SMK A, kategori mudah pada SMK C dan kategori sukar pada SMK B. Soal pada kategori sedang terdapat pada SMK A yaitu sebesar $72.5 \%$. Soal dengan kategori sedang menandakan jika soal tersebut dapat dijawab oleh peserta tes yang pandai (kelompok atas) dengan peserta tes yang kurang pandai (kelompok bawah). Soal SMK B yaitu sebesar 71,4\% sebanyak 25 soal dengan kategori sukar menandakan jika soal tersebut banyak siswa yang tidak mampu mengerjakannya. Makin tinggi tingkat kesukaran butir soal itu berarti soal itu makin sulit. Soal dikatakan mudah karena kecil proposisi peserta tes menjawab dengan benar suatu butir soal. Makin rendah tingkat kesukaran butir soal itu maka soal tersebut makin mudah.

\section{Kesimpulan}

Kesimpulan penelitian tentang kualitas soal penilaian akhir semester (PAS) buatan guru kimia kelas X SMK Jurusan Teknologi dan Rekayas di Kabupaten Kotawaringin Timur pada semester ganjil tahun ajaran 2018/2019 adalah sebagai berikut: 1) Kelas X SMK Jurusan Teknologi dan Rekayasa di Kabupaten Kotawaringin timur yaitu SMKN 2 Sampit, SMKN 3 Sampit, SMK Muhammadiyah Sampit menerapkan kurikulum 2013. 2) Kesesuaian butir soal terhadap aspek materi, konstruksi, dan bahasa dalam bentuk soal pilihan ganda pada kelas X SMK Jurusan Teknologi dan Rekayasa di Kabupaten Kotawaringin Timur sebesar 98,72\% dengan kategori baik. 3) Kesesuaian butir soal dengan kompetensi dasar sebesar 69,5\% dengan kategori cukup sesuai. 3) Distribusi jenjang ranah kognitif taksonomi bloom yang terukur pada tiga seluruh soal dari tiga SMK yang berada di Kabupaten Kotawaringin Timur adalah 52 (55\%) soal didominasi pada tingkat mengingat, 23 (24\%) soal tingkat memahami, $17(18 \%)$ soal tingkat menerapkan, pada tingkat menganalisis 3 (3\%) soal. 4) Kualitas soal PAS berdasarkan indeks daya beda, indeks kesukaran dan distraktor diperoleh persentase rata-rata adalah $63 \%$ soal berkualitas baik dan $37 \%$ soal berkualitas jelek. 5) Kesalahan konstruksi yang paling banyak ditemukan adalah : a) Pokok soal tidak dirumuskan secara tegas, jelas, dan singkat, b) Pilihan jawaban jawaban tidak homogen dan logis. 


\section{Daftar Rujukan}

Arifin, Zainal. 2009. Evaluasi Pembelajaran. Bandung: PT Remaja Rosdakarya.

Afrian, R., Islami, Z. R., \& Mustika, F. 2018. Pembinaan Pembuatan Tes Buatan Guru Soal Mata Pelajaran Geografi SMA/MA Kota Langsa. Jurnal VokasiPoliteknik Negeri Lhokseumawe.

Daryanto. 2008. Evaluasi Pendidikan. Jakarta: Rineka Cipta.

Depdiknas. 2017. Direktorat Pembinaan Sekolah Menengah Kejuruan. Jakarta: Depdiknas

Hardiyaningrum, S. 2013. Kualitas Paket-paket Soal Uji coba Ujian Nasional Kimia Di SMA 1 Kudus Tahun Ajaran 2012/2013. Doctoral dissertation Universitas Negeri Semarang

Hidayatullah, Erick. 2008.Analisis Buku Ajar bidang studi sains. Jakarta:UIN

Hamdi, A. S., \& Bahruddin, E. 2015. Metode penelitian kuantitatif aplikasi dalam pendidikan. Deepublish

Johnson, L. A. 2008. Relationship of Institutional Methods to Students Engagement in Two Public High Schools. American Secondary Education.

Kartowagiran, B. 2005. Item and Test Analysis ITEMAN. Yogyakarta: Makalah Penyegaran Metodologi Penelitian Pascasarjana UNY Yogyakarta

Marlina. 2018. Kualitas Soal Penilaian Akhir Semester (PAS) Buatan Guru Mata Pelajaran Kimia Kelas X MIA SMA di Kotawaringin timur Pada Semester Ganjil Tahun Ajaran 2017/2018. Palangka Raya: Universitas Palangka Raya.

Novianto, Dina. 2012. Analisis Kualitas Soal Ulangan Akhir Semester II Mata Pelajaran Ekonomi Kelas X SMA Negeri 3 Jember Semester Genap Tahun Ajaran 2011-2012. Universitas Jember.

Purwanto. 2016. Evaluasi Hasil Belajar. Yogyakarta: Pustaka Pelajar.

Slameto. 2001. Evaluasi Pendidikan. Jakarta: Bumi Aksara.

Widoyoko, E. P. 2009. Evaluasi program pembelajaran Vol. 91. Yogyakarta: Pustaka Pelajar.

Yaspuri, M. 2014. Analisis Butir Soal Ujian Tengah Semester Mata Pelajaran Ilmu Pengatahuan Sosial Kelas IV B Dengan Program Anestes Versi 4.

Yamin, S., \& Kurniawan, H. 2009. SPSS Complete: Teknik Analisis Statistik Terlengkap dengan Software SPSS. Jakarta: Salemba Infotek. 